\title{
Biological Activity of Extracts of the Starfish Asterias amurensis
}

\author{
Hye-Jin Go ${ }^{1}$, Mi Jeong $\mathrm{Jo}^{2}$, Tae Young Kim¹, Yong-Ki Hong ${ }^{1}$, Gun-Do Kim², Byung-Woo Lee ${ }^{3}$ and \\ Nam Gyu Park ${ }^{1 *}$
}

${ }^{1}$ Department of Biotechnology, College of Fisheries Sciences, Pukyong National University, Busan 608-737, Korea

${ }^{2}$ Department of Microbiology, College of Natural Sciences, Pukyong National University, Busan 608-737, Korea

${ }^{3}$ Department of Materials System Engineering, College of Engineering, Pukyong National University, Busan 608-737, Korea

Received February 12, 2013 /Revised March 13, 2014 /Accepted March 18, 2014

\begin{abstract}
Nowadays, starfish is one of problems about interruption of marine ecosystem, so many researchers are focusing on application of the starfish (Asterias amurensis). In this study, we investigated the contractile and relaxant activity of the smooth muscles and the antimicrobial and antioxidant activity of six different tissues (muscle, gut, liver, tube feet, gonads, and body) of $A$. amurensis. Frozen samples were extracted with distilled water containing 1\% acetic acid. Extracts from all the tissues, except the body tissue, showed potent antimicrobial activity against Escherichia coli D31. The dorsal retractor muscles (DRM) of muscle and gut extracts showed strong contraction responses. On the other hand, contractile activity on esophagus of squid Todarodes pacificus could be detected in all tissues tested. The contractile activity of the liver extract was higher than that of the other tissues. The body, tube feet, and liver extracts showed the contractile activity on the intestine of the panther puffer fish (Takifugu pardalis). Relaxation response on the DRM of starfish (A. pectinifera) was observed in all tissues tested. Increased antioxidant activity was observed in the gut, liver, and body extracts. The results suggest that the starfish $(A$. amurensis $)$ is a potential source of novel bioactive compounds.
\end{abstract}

Key words : Antimicrobial activity, antioxidant activity, contraction and relaxation, starfish Asterias amurensis

\section{서 론}

해양생물인 스펀지, 말미잘, 산호 및 어류로부터 신경성 펩 타이드, 생체방어물질 및 항산화 활성을 지닌 다양한 생리활 성물질이 정제되고 있다[6]. 신경성 펩타이드는 신호전달물질 로서 신경계에서 신호조절 및 전달 역할을 하며, 평활근과 혈 관의 수축 및 이완, 통증 등에 관련된 활성을 나타내어 생체의 항상성 유지에 중요한 역할을 담당하고 있다 $[8,20]$. 대표적인 신호전달물질인 eledoisin이 낙지로부터 분리된 후[11], 척추 동물 및 무척추동물의 다양한 조직으로부터 신경성 펩타이드 들(neuropeptides)이 발견되었다[20]. 최근 이들 신경전달물질 들 중 어류에서 척추동물의 gonadotropin-releasing hormone $(\mathrm{GnRH})$ 와 유사한 GnRH-like peptide가 발견되었고[32], 해삼 (Stichopus japonicus)의 longitudinal muscle과 body wall로부 터 평활근에 수축활성을 나타내는 펩타이드가 정제되었다[13, 15].

\footnotetext{
*Corresponding author

*Tel : +82-51-629-5867, Fax : +82-51-629-5863

E-mail : ngpark@pknu.ac.kr

This is an Open-Access article distributed under the terms of the Creative Commons Attribution Non-Commercial License (http://creativecommons.org/licenses/by-nc/3.0) which permits unrestricted non-commercial use, distribution, and reproduction in any medium, provided the original work is properly cited.
}

한편, 수산생물들은 수중에서 생활하기 때문에 육상생물보 다 직접 세균에 감염 될 위험성이 더 높지만, 육상생물과 유사 하게 미생물들로부터 자기 자신들을 보호하기 위한 면역체계 를 지니고 있다[12]. 척추동물에는 선천면역(innate immunity) 과 적응면역(adaptive immunity)이 각각 잘 발달되어 있지만 무척추동물에서는 선천면역만을 지니고 있다. 따라서 여러 가 지의 선천면역 요소들 중에서 비 특이적이고 빠른 반응성을 가지는 항균활성 펩타이드에 대한 관심이 증가되고 있으며, 해양 무척추동물인 해면[25], 갑각류[4, 27], 연체류[2, 14, 26], 성게[23], 갯지렁이 및 해파리[28, 29]로부터 항균성 펩타이드 가 발견되었다.

항산화제는 식품첨가물로 이용되면서 식품산업에 있어서 중요한 위치를 차지하는 물질이었으나 free radical이 노화, 암, 돌연변이를 일으키는 유인으로 지적되면서 항노화 관련 질병 치료제로 주목을 받아 왔다 $[1,33]$. 항산화제로써 사용되어 온 $\alpha$-tocopherol, vitamin C, tert-butylhydroxytoluene (BHT), tert-butylhydroxyanisol (BHA)는 독성이 강하고, 저활성 및 용도의 한계성으로 인해 사용을 제한 받고 있기 때문에, 이들 보다 활성이 높은 동시에 안전한 항산화제를 천연물로부터 발견하고자 세균, 조류, 식물을 이용한 연구가 활발히 진행되 어 오고 있다 $[17,19,31]$. 특히 해양생물로부터 자외선에 의한 피해를 줄이기 위해서 유해한 파장 범위를 흡수하는 mycosporin-like amino acids (MAAs)가 존재함이 보고되었다[7]. 
따라서 불가사리 조직에도 지금까지 알려진 물질과 유사한 또는 새로운 물질들이 존재하리라 생각되어 본 연구에서는 아무르불가사리(Asterias amurensis)를 사용하여 조직별로 추 출한 후 평활근 수축과 이완작용, 항균 및 항산화 활성을 살펴 보았다.

\section{재료 및 방법}

\section{일반시약}

Tryptic soy broth (TSB), agarose (Low EEO) 및 1,1-diphenyl-2-picrylhydrazyl (DPPH)는 Sigma사(St. Louis, USA) 에서 구입하였다.

\section{조직 추출물의 조제}

실험에 사용한 아무르불가사리(전장 15.0-20.0 cm)는 부산 의 기장에서 채집하여 순환되는 해수수조에서 일정한 수온을 유지하여 추출직전까지 정치시켰다. 10 마리의 아무르불가사 리를 해부하여 몸체 껍질(body), 간(liver), 생식선(gonad), 근 육(muscle), 위를 포함한 소화관(gut) 및 관족(tube feet) 조직 을 분리한 뒤 $1 \%$ 초산과 $1: 3(\mathrm{~V} / \mathrm{V})$ 으로 혼합하여 끓인 후, 블랜더로 균질화하여 $4{ }^{\circ} \mathrm{C}$ 에서 30 분 동안 $15,000 \times \mathrm{g}$ 로 원심 분 리하였다. 상층액은 각각 모아두고, 각 조직 침전물은 위와 동일한 과정을 2회 반복하여 첫 번째 상층액과 함께 동결 건조 하였다.

\section{항균 활성 측정}

각각의 조직에 대한 추출물들을 사용하여 항균활성을 측정 하였다. 항균활성 측정 방법으로는 서로 다른 농도를 포함한 두 층의 배지를 사용하는 ultrasensitive radial diffusion assay (URDA)법을 이용하였다[22]. URDA에 사용된 균주는 North Carolina State University의 Edward J. Noga 교수로부터 분양 받은 그람 음성균인 Escherichia coli D31을 사용하였다. 우선 배지 및 배양온도에서 18시간 동안 전배양 후 BioMerieux Vitek, Inc. Colorimeter (Product No. 52-1210, BioMerieux, Inc., USA)를 사용하여 농도를 $84 \% \mathrm{~T}\left(\fallingdotseq 1 \times 10^{8} \mathrm{CFU} / \mathrm{ml}\right)$ 가 되게 맞추었다. 그 후, $9.5 \mathrm{ml}$ 의 $0.03 \% \mathrm{TSB}, 1 \%$ Type I agarose 및 $10 \mathrm{mM}$ phosphate buffer (pH 6.5)를 포함하는 underlay gel에 $84 \% \mathrm{~T}$ 로 희석된 균 $0.5 \mathrm{ml}$ 을 넣고 잘 섞은 후에 plate에 편평하게 부어 굳히고, 굳은 plate에 punch를 사용하여 직경 $2.5 \mathrm{~mm}$ 의 well을 뚫은 후에, 추출물 총 부피의 $1 / 10$ 을 도입시 켰다. 모든 sample은 $0.01 \%$ acetic acid $(\mathrm{pH} 4.0)$ 에 녹여 활성을 측정하였으며, negative control로 $0.01 \%$ acetic acid (pH 4.0) $5 \mu \mathrm{l}$ 를 사용하여 용매에 의한 영향이 없음을 확인하였다. 추출 물이 배지에 스며들면 3시간 동안 1차 배양한 후, 그 위에 10 $\mathrm{ml}$ 의 $6 \% \mathrm{TSB}, 1 \%$ Type I agarose 및 $10 \mathrm{mM}$ phosphate buffer $(\mathrm{pH}$ 6.5)를 포함하는 overlay gel을 붓고 굳힌 후에 동일한
온도에서 18 시간 동안 2차 배양하였다. 다음 날, well주위의 clear zone의 유무 및 clear zone diameter $(\mathrm{mm})$ 를 확인하여 활성의 세기를 측정하였다.

\section{별불가사리 dorsal retractor muscle (DRM)의 수축 및 이완 활성 측정}

별불가사리의 eye spot을 제거한 후 배면과 복면을 분리하 여 5 개 팔을 따라 중앙을 가로지르는 $\mathrm{DRM}$ 을 mess로 분리하 여 $10.0 \mathrm{~mm}$ 정도의 단편으로 만들었다. 준비된 각 단편들은 반응조 내의 지지대에 고정시키고, 위쪽은 physiography system (NECSanei, Tokyo, Japan)의 isometric transducer에 연 결하여 resting tension이 $1.0 \mathrm{~g}$ 이 되도록 90 분간 평형화 시켰 다. 수축활성을 측정하기 위해, 별불가사리 DRM 조직의 tension이 $1.0 \mathrm{~g}$ 이 유지되면 acetylcholine (Ach) $10^{4} \mathrm{M}$ 을 투여하 여 활성화시켰다. 불가사리 조직 추출물들은 추출물의 총 부 피의 $1 / 10$ 을 사용하여 인공해수에 녹인 후 반응조에 투여하여 활성을 확인하였다.

조직의 tension이 $1.0 \mathrm{~g}$ 이 유지되면 $10^{-4} \mathrm{M} \mathrm{Ach}$ 을 투여하여 활성화 시켰고, 15 분후 펩타이드를 농도별로 누적 투여하였 다. 수축활성은 Ach에 대한 장관의 수축반응을 $100 \%$ 로 하고, 추출물에 대한 장관의 반응 정도는 Ach반응의 크기와 비교하 여 나타내었다.

한편 각 조직 추출물의 이완활성을 측정하기 위해서, 조직 의 tension이 $1.0 \mathrm{~g}$ 이 유지되면 $10^{-4} \mathrm{M} \mathrm{Ach}$ 을 투여하여 활성화 시켰고, 15 분 후 $10^{-4} \mathrm{M} \mathrm{Ach}$ 을 투여하여 근육을 수축시킨 후, 조직 추출물을 반응조에 투여하여 이완활성을 확인하였다. 이 완활성은 $10^{-4} \mathrm{M} \mathrm{Ach}$ 의 최대수축작용을 $100 \%$ 로 하여 상대적 이완 \%로서 나타냈다. 모든 과정은 $55 \mathrm{mM} \mathrm{Mg}^{2+}$ artificial sea water (인공해수, $\mathrm{ASW}$ )하에서 행하였으며, 조성은 다음과 같 다: $\mathrm{NaCl} 445 \mathrm{mM}, \mathrm{KCl} 10 \mathrm{mM}, \mathrm{CaCl}_{2} \cdot 2 \mathrm{H}_{2} \mathrm{O} 10 \mathrm{mM}, \mathrm{MgCl}_{2}$. $6 \mathrm{H}_{2} \mathrm{O} 55 \mathrm{mM}$, Glucose $10 \mathrm{mM}$ and Tris- $\mathrm{HCl}$ (pH 7.8) $10 \mathrm{mM}$.

\section{오징어 소화관에서의 수축활성 측정}

오징어를 반으로 갈라 뇌 아래에서부터 간의 뒤로 이어지는 소화관의 중앙부분을 $7.0 \mathrm{~cm}$ 로 떼어내어 adipose 등을 제거한 후, 장관의 길이가 약 $1.0 \mathrm{~cm}$ 가 되도록 단편을 만들어 활성측 정에 사용하였다. 모든 과정은 buffer하에서 행하였으며, 조성 은 다음과 같다: $\mathrm{NaCl} 466 \mathrm{mM}, \mathrm{MgCl}_{2} 54 \mathrm{mM}, \mathrm{CaCl}_{2} 11 \mathrm{mM}$, $\mathrm{KCl} 10 \mathrm{mM}, \mathrm{NaHCO}_{3} 3 \mathrm{mM}, \mathrm{Na}-\mathrm{HEPES} 10 \mathrm{mM}$. 준비된 식도 의 아래쪽은 $2 \mathrm{ml}$ 의 반응조에 고정시키고 위쪽은 physiography system의 isometric transducer에 연결하여 $1.5 \mathrm{~g}$ 의 장 력을 준 뒤, 15 분 간격으로 완충용액을 교체하면서 60 분간 평 형화 시켰다. 수축활성 측정은 실온에서 반응조 내에 공기를 주입시켜 주면서 안정화시킨 후 $10^{-5} \mathrm{M}$ Carbachol (Carb)을 15 분 간격으로 3 회 투여하여 조직을 활성화 시켰다. 각 추출물 은 총 부피의 $1 / 10$ 을 사용하여 반응조에 투여하였다. 시료들 
은 주입한 후 수축활성을 측정하여 physiography상에 기록하 였다.

\section{졸복 장관 평활근에 대한 수축활성 측정}

졸복 장관표본을 만들기 위해 먼저 중추신경을 절단하여 복부를 절개한 후, hind gut 로부터 $1.0 \mathrm{~cm}$ 정도 윗부분에 해당 하는 장관을 약 2.0-3.0 $\mathrm{cm}$ 길이로 적출하였다. 모세혈관 및 adipose 등을 제거한 후, 장관의 길이가 약 $1.0 \mathrm{~cm}$ 가 되도록 단편을 만들었다. 이 과정은 buffer상에서 행하였으며, 조성은 다음과 같다: $\mathrm{NaCl} 165 \mathrm{mM}, \mathrm{KCl} 3 \mathrm{mM}, \mathrm{MgSO}_{4} \cdot 7 \mathrm{H}_{2} \mathrm{O} 1.25$ $\mathrm{mM}, \mathrm{NaHCO}_{3} 2 \mathrm{mM}, \mathrm{CaCl}_{2} 2 \mathrm{H}_{2} \mathrm{O} 1.5 \mathrm{mM}$, Glucose $10 \mathrm{mM}$ ( $\mathrm{pH}$ 7.4). 준비된 장관표본은 $2 \mathrm{ml}$ 의 반응조에 고정시키고 위 쪽은 physiography system의 isometric transducer에 연결하 여 $1.5 \mathrm{~g}$ 의 장력을 준 뒤, 15 분 간격으로 완충용액을 교체하면 서 60 분간 평형화시켰다. 수축활성 측정은 실온에서 반응조 내에 공기를 주입시켜 주면서 안정화시킨 후 $10^{-7} \mathrm{M} \mathrm{Ach}$ 을 15 분 간격으로 3 회 투여하여 조직을 활성화시켰다. 각 추출물 은 총 부피의 $1 / 10$ 을 사용하여 반응조에 투여하였다. 시료들 은 주입한 후 수축활성을 측정하여 physiography상에 기록하 였다. 수축활성은 $10^{-7} \mathrm{M}$ Ach 에 의해 유도된 근육의 수축반응 을 $100 \%$ 로 하고, 각 추출물에 대한 장관의 반응 정도는 Ach 반응의 크기와 비교하여 나타내었다.

\section{항산화 활성의 측정}

각 추출물은 수분을 완전히 제거하여 $4 \mathrm{ml}$ methanol에 용 해시켰다. DPPH는 methanol에 녹여 $1.5 \times 10^{-4} \mathrm{M}$ 이 되도록 준 비하였다. 각각의 추출물들로부터 $3 \mathrm{mg}$ 을 취하여 $0.01 \%$ 초산 용액 $1 \mathrm{ml}$ 에 녹인 후, 총 시료의 $1 / 10$ 씩을 사용하여 활성을 측정하였다. $1 \mathrm{ml} \mathrm{DPPH}$ solution과 추출물의 $1 / 10$ 이 포함된 $4 \mathrm{ml}$ 를 UV cuvette에서 혼합하여 즉시 $520 \mathrm{~nm}$ 에서 $\mathrm{OD}$ 값을 측정하였고 실온에서 30 분간 방치한 후 $\mathrm{OD}$ 값을 다시 측정하 였다. 대조군으로 $1 \mathrm{ml} \mathrm{DPPH}$ 용액에 $4 \mathrm{ml}$ methanol을 혼합한 것을 사용하였다. Radical scavenging effect (RSE)의 활성은 다음 식으로 계산하였다.

RSE $(\%)=[($ O.D. of Standard - O.D. of Sample $) /$ O.D. of Standard] $\times 100$

\section{결과 및 고찰}

\section{아무르불가사리 추출물들의 항균 활성}

아무르불가사리의 각 조직으로부터 추출한 추출물들의 항 균활성을 조사하기 위해 그람 음성균인 E. coli $\mathrm{D} 31$ 에 대해 항균활성을 측정하였다. 본 실험에 사용된 조직 추출물들의 항균활성은 서로간에 약간의 차이는 있지만, 모두 clear zone 의 크기가 $10.0 \mathrm{~mm}$ 이상으로 강한 항균활성을 나타냈다(Fig. 1). 아무르불가사리의 관족은 $20.2 \mathrm{~mm}$, 근육은 $17.2 \mathrm{~mm}$, 간은

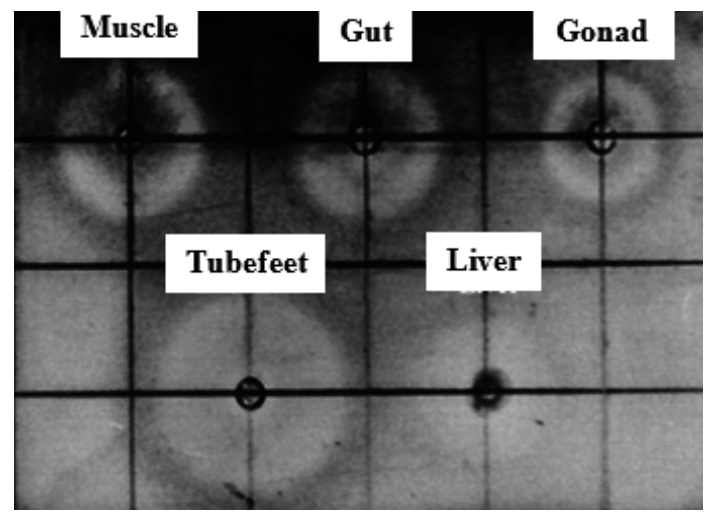

Fig. 1. Antimicrobial activity of various tissues' extracts of the starfish A. amurensis against E. coli D31.

$14.7 \mathrm{~mm}$, 생식선은 $13.9 \mathrm{~mm}$, 소화관은 $12.8 \mathrm{~mm}$ 의 항균활성 을 나타내었다. 특히 관족 추출물은 다른 조직들에 비해 더 강한 항균활성을 나타내었다. 관족은 불가사리의 움직임을 조 절하고 먹이를 잡는 역할을 담당하고 있으며, 외부 미생물에 대해 일차적으로 접촉하는 부위이다. 이러한 역할을 수행할 때 관족 끝에서 점액질이 분비된다고 알려져 있다. 또한 관족 은 아가미의 보조 역할을 한다고 알려져 있다.

최근 먹장어, 넙치 등의 피부 분비물 및 굴의 아가미로부터 항균 단백질 및 펩타이드가 발견되었다[3, 34-36]. 이러한 물질 들은 면역반응에서 선천성 면역 반응계에서 일차적으로 자신 의 생체를 방어하기 위해 분비되는 물질로 알려져 있다. 따라 서 관족 추출물이 다른 조직들에 비해 높은 활성을 나타낸 이유는 아마도 이러한 선천성 면역반응에 관여하고 있는 항균 성 단백질 및 펩타이드를 비롯한 다양한 종류의 물질들이 많 이 존재하여 나타난 것이라 예상할 수 있다.

또한, 척추동물의 간 및 불가사리의 생식선에서 항균성 단 백질 및 펩타이드가 최근 발견되었는데 $[24,30]$, 본 연구에서 불가사리의 조직 중 간과 생식선에서 관족 추출물의 약 $70.0 \%$ 에 해당하는 활성을 나타내었다. 이러한 결과는 불가사리에도 척추동물에서 발견된 물질과 유사하거나 구조가 다른 물질이 존재할 가능성을 제시한다. 흥미롭게도 근육조직 추출물에서 도 관족 추출물과 유사하게 높은 항균활성이 나타나는데, 이 러한 현상은 근육조직이 불가사리 내부에 존재하는 체액에 직접 노출되어 있기 때문에 체액에 존재하는 미생물로부터 자신을 보호하기 위한 반응의 결과로 예상된다. 따라서 불가 사리로부터 새로운 항균성 물질이 정제된다면 인간과 다른 생물체에 피해를 주고 있는 불가사리로부터 고부가가치를 지 닌 물질을 개발 및 활용할 수 있는 계기가 되리라 생각된다.

\section{별불가사리 DRM, 오징어 식도 및 졸복의 장관 평활근에 대한 수축활성}

불가사리 조직 추출물들의 근육 수축작용을 조사하기 위해 서 별불가사리 DRM, 오징어 식도 및 졸복의 장관을 사용하였 
Table 1 . The contractile activity of various tissues' extracts of the starfish $A$. amurensis on the smooth muscle of the other organisms

\begin{tabular}{lccc}
\hline \multirow{2}{*}{ Sample } & \multicolumn{3}{c}{ Contractile activity (\%) } \\
\cline { 2 - 4 } & DRM of & Esophagus of & Intestine of \\
& A. pectinifera & T. pacificus & T. pardalis \\
\hline Muscle & 90 & 75.8 & N.T. \\
Gut & 80 & 64.4 & N.T \\
Gonad & 20 & 39.6 & N.T \\
Liver & 4 & 137.6 & 36.4 \\
Tube feet & 25 & 72.3 & 84.1 \\
Body & N.T $^{*}$ & 69.3 & 86.4 \\
\hline
\end{tabular}

*N.T.: not tested.

다. Table 1 은 이들 3 종류의 평활근에 대한 조직 추출물의 근 수축 반응을 나타낸다. 근육 및 소화관 추출물은 별불가사리 $\mathrm{DRM}$ 에 대해 강한 수축반응을 나타냈다(Fig. 2A). 근육 추출물 은 $\mathrm{DRM}$ 에 대해 반응시간 동안 수축반응이 유지되었지만, 소 화관 추출물에 의한 수축반응은 최대 수축 후 1 분 이내에 정상 적인 자율운동 상태로 되돌아 왔다. 한편 관족 및 간 추출물은 $\mathrm{DRM}$ 에 대해 약한 수축반응을 나타냈다. 그러나 간 추출물은 거의 수축반응을 보이지 않았다.

오징어의 식도에 대한 각 추출물의 근 수축활성은 Table 1 와 Fig. $2 \mathrm{~B}$ 에 나타낸 바와 같이 $10^{-5} \mathrm{M}$ Carb에 의해 유도된
근육의 수축반응을 $100 \%$ 로 하고, 각 추출물에 대한 장관의 반응 정도는 Carb반응의 크기와 비교하여 나타내었다. 불가사 리 간 $(137.6 \%)$ 은 매우 강한 수축반응을 나타냈으며, 근육 $(75.8 \%)$, 관족 $(72.3 \%)$, 껍질 $(69.3 \%)$ 및 소화관 $(64.4 \%)$ 추출물들 은 $50.0 \%$ 이상의 높은 반응을 나타내었다. 생식선 $(39.6 \%)$ 은 수축활성을 나타내었지만 다른 조직들에 비해 낮은 반응을 나타내었다. 간 추출물은 식도 조직에 대해 계속적인 수축반 응을 나타내었으며, 소화관 및 관족 추출물은 수축반응이 진 행되다가 일정시간이 지난 후에 평형상태를 유지하였다. 특 히, 껍질 추출물은 오징어 식도 평활근에 대해 수축활성의 톤 을 증가시켰지만, 점차적으로 수축상태가 감소되어 처음의 자 율운동의 상태로 복귀되었다(Fig. 2B). 한편, 졸복의 장관의 경 우는 관족 $(84.1 \%)$ 및 껍질 $(86.4 \%)$ 추출물에서 높은 수축활성 을 나타내었지만, 간 $(36.4 \%)$ 추출물은 비교적 낮은 수축활성 을 보였다.

\section{별불가사리 DRM에 대한 이완 활성}

별불가사리 DRM에 대한 각 추출물의 이완활성은 Fig. 3에 나타내었다. 간 추출물은 $85.7 \%$ 의 이완활성을 나타내었으며, 소화관은 $68.8 \%$, 관족은 $42.9 \%$, 근육은 $41.4 \%$ 및 생식선은 $14.3 \%$ 의 이완활성을 보였다. 한편, 해삼으로부터 수축활성을 지닌 물질뿐만 아니라 이완활성을 나타내는 2종류의 물질이 발견되었다[5,16]. 그 이외에 Asterias rubens와 Asterias forbesi

\section{A. The DRM of the starfish Asterias pectinifera}
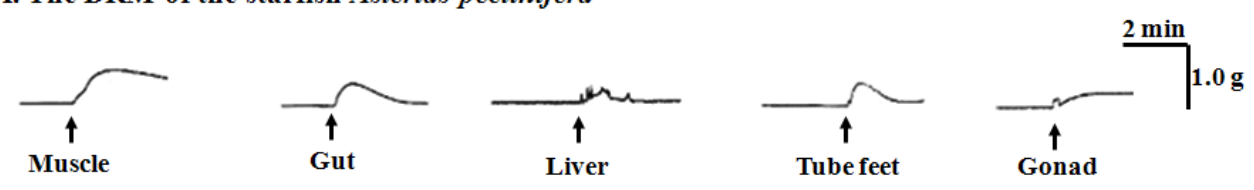

B. The esophagus of squid, Todarodes pacificus

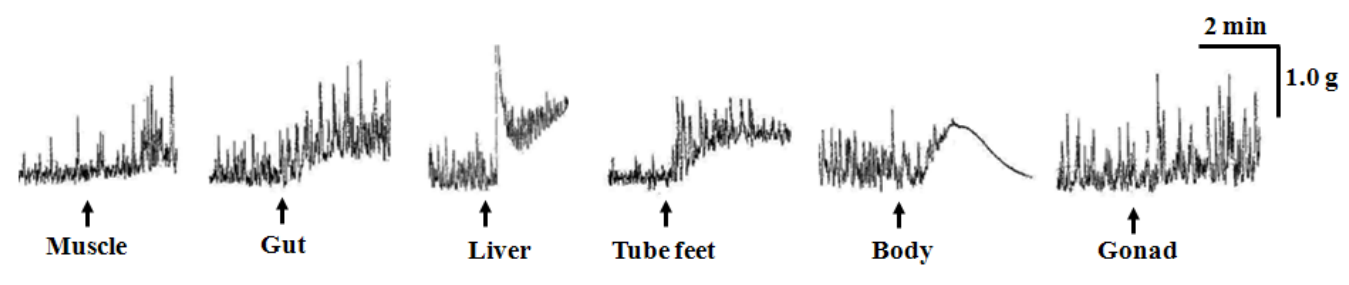

C. The intestine of panther puffer, Takifugu pardalis

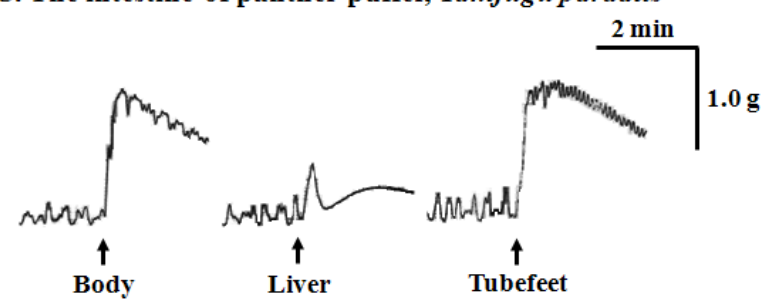

Fig. 2. The contractile activity of various tissues' extracts of the starfish $A$. amurensis on the smooth muscles. A; DRM of the starfish, A. pectinifera, B; Esophagus of the squid, T. pacificus, C; Intestine of the panther puffer, T. pardalis. The extract was applied at the time indicated by arrows. 


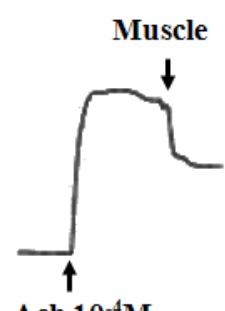

Ach $10^{-4} \mathbf{M}$
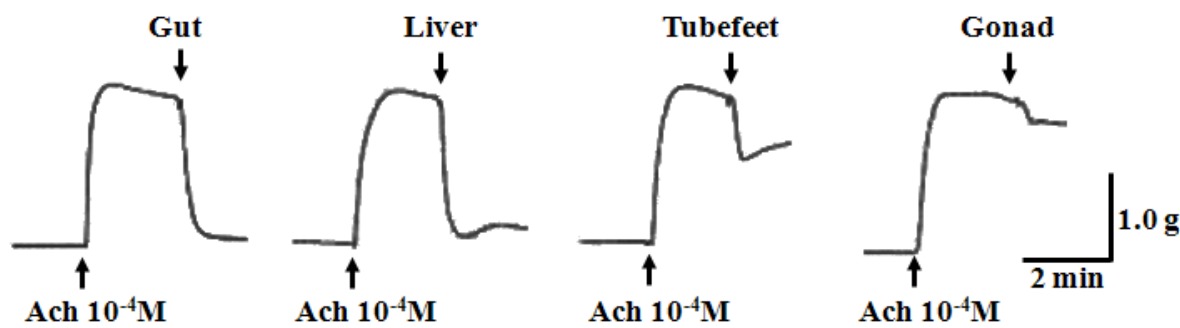

Fig. 3. The relaxant activity of various tissues' extracts of the starfish $A$. amurensis on the starfish $A$. pectinifera DRM. The extract was applied at the time indicated by arrows.

Table 2. In vitro DPPH radical scavenging activity of various tissue's extracts of the starfish $A$. amurensis

\begin{tabular}{lc}
\hline Sample & Radical scavenging effect (RSE, \%) \\
\hline Muscle & 35.9 \\
Gut & 94.1 \\
Gonad & 14 \\
Liver & 97.5 \\
Tube feet & 8.1 \\
Body & 100 \\
\hline
\end{tabular}

의 radial nerve cords로부터 FMRFamide 관련 물질이 정제되 었고, 이들은 불가사리 cardiac stomach에 대하여 이완활성을 나타냈다 $[9,10]$. 뿐만 아니라 Asterias amurensis 의 radial nerve 로부터 S-S 결합을 지니고 있는 gonad-stimulating substance (GSS)도 분리되었다[16]. 그러나 현재까지 아무르불가사리 추 출물들을 사용하여 신경성 전달물질에 대한 연구는 많이 이루 어 지지 않고 있다. 따라서 본 연구의 결과는 다양한 불가사리 조직 내에 생체의 항상성에 관여하는 신경성 조절물질이 존재 한다는 것을 나타내고 있기 때문에 이들 조직으로부터 아직까 지 발견되지 않은 새로운 물질들을 발견하기 위한 중요한 재 료로 활용할 수 있음을 제시한다.

\section{항산화 활성}

불가사리 조직 추출물들의 항산화 활성을 알아보기 위해서 $\mathrm{DPPH}$ 를 사용하여 RSE를 조사하였다. 항산화 활성 측정에 대 한 대조구로서 vitamin C를 $0.8,4,20,100$ 및 $500 \mu \mathrm{g} / \mathrm{ml}$ 사용 하였으며, RSE는 각각 $13,19,60,88$ 및 $90 \%$ 를 나타냈다. Table 2는 별불가사리 조직들의 추출물에 대한 $\mathrm{DPPH}$ 소거능을 지표 로 한 항산화 활성을 나타낸 것이다. 껍질 추출물은 $100 \%$, 간 추출물은 $97.5 \%$, 소화관 추출물은 $94.1 \%$, 근육은 $35.9 \%$ 의 활 성을 나타내었다. 그러나, 생식선 $(14.0 \%)$ 및 관족 $(8.1 \%)$ 은 다 른 조직들에 비교적 약한 항산화 효과를 나타내었다. 최근 아 무르불가사리(A. amurensis)로부터 피부주름 억제활성[21], 별 불가사리 추출물로부터 면역세포 활성화 효과[18] 등이 확인 되었다. 따라서 새로운 항산화물질을 개발하기 위해 불가사리 의 다양한 조직들이 유용성을 지니며 필수적인 연구대상이 될 수 있음을 시사해준다.

\section{감사의 글}

본 연구는 환경부의 2013년 차세대 에코 이노베이션 기술 개발 사업(2013000130002)에서 지원받았습니다.

\section{References}

1. Ames, B. N., Shigenaga, M. K. and Hagen, T. M. 1993. Oxidants, antioxidants, and the degenerative diseases of aging. Proc Natl Acad Sci USA 90, 7915-7922.

2. Charlet, M., Chernysh, S., Philippe, H., Hetru, C., Hoffmann, J. A. and Bulet, P. 1996. Innate immunity. Isolation of several, cysteine-rich antimicrobial peptides from the blood of a mollusk, Mytilus edulis. J Biol Chem 271, 21808-21813.

3. Cole, A. M., Weis, P. and Diamond, G. 1997. Isolation and characterization of pleurocidin, an antimicrobial peptide in the skin secretions of winter flounder. J Biol Chem 272, 12008-12013.

4. Destoumieux, D., Bulet, P., Loew, D., Van, D. A., Rodriguez, J. and Bachere, E. 1997. Penaeidins, a new family of antimicrobial peptides isolated from the shrimp Penaeus vannamei (Decapoda). J Biol Chem 272, 28398-28406.

5. Diaz-Miranda, L., Blanco, R. E. and Garcia-Arraras, J. E. 1995. Localization of the heptapeptide GFSKLYFamide in the sea cucumber Holothuria glaberrima (Echinodermata): a light and electron microscopic study. J Comp Neurol 352, 626-640.

6. Donia, M. and Hamann, M. T. 2003. Marine natural products and their potential applications as anti-infective agents. Lancet Infect Dis 3, 338-348.

7. Dunlap, W. C. and Yamamoto, Y. 1995. Small-molecule antioxidants in marine organisms: antioxidant activity of mycosporine-glycine. Comp Biochem Physiol 112, 105-114.

8. Elliott, G. R. and Barchas, J. D. 1979. Neuroregulators: neurotransmitters and neuromodulators. Behavioural and Brain Sciences 2, 423-424.

9. Elphick, M. R. and Melarange, R. 2001. Neural control of muscle relaxation in echinoderms. J Exp Biol 204, 875-885.

10. Elphick, M. R., Price, D. A., Lee, T. D. and Thorndyke, M. C. 1991. The SALMFamides: a new family of neuropeptides in the starfish Asterias rubens. J Exp Biol 198, 2519-2525.

11. Erspamer, V. and Anastasi, A. 1962. Structure and pharmacological actions of eledoisin, the active endecapeptide of 
the posterior salivary glands of eledone. Experientia 18, 58-59.

12. Hancock, R. E. W. and Diamond, G. 2000. The role of cationic antimicrobial peptides in innate host defences. Trends Microbiol 8, 402-410.

13. Holmgren, S. and Jensen, J. 2001. Evolution of vertebrate neuropeptides. Brain Res Bull 55, 723-735.

14. Iijima, N., Tanimoto, N., Emoto, Y., Morita, Y., Uematsu, K., Murakami, T. and Nakai, T. 2003. Purification and characterization of three isoforms of chrysophsin, a novel antimicrobial peptide in the gills of the red sea bream. Chrysophrys major. Eur J Biochem 270, 675-686.

15. Iwakoshi, E., Ohtani, M., Takahashi, T., Muneoka, Y., Ikeda, T., Fujita, T., Minakata, H. and Nomoto, K. 1995. Comparative aspects of structure and action of bioactive peptides isolated from the sea cucumber Stichopus japanicus, pp. 261-264. In: Peptide Chemistry, Ohno, M. (eds.), Protein Research Foundation: Osaka, Japan.

16. Kanatani, H., Ikegami, S., Shirai, H., Oide, H. and Tamura, S. 1971. Purification of gonad-stimulating substance obtained from radial nerves of starfish. Dev Growth Differ 13, 151-164.

17. Kang, D. G., Yun, C. K. and Lee, H. S. 2003. Screening and comparison of antioxidant activity of solvent extracts of herbal medicines used in Korea. J Ethnopharmacol 87, 231-236.

18. Kim, I. H., Seo, J. K., Kim, U. J., Kim, C. H., Ko, H. J., Kim, C. H. and Park, N. K. 2001. Screening and refining of bioactive substance from Asterina pectinifera, pp. 215-216. Proceeding of Spring symposium of marine society organization. October 19, Daegu, Korea.

19. Kim, W. G., Kim, J. P., Koshino, H., Shin-Ya, K., Seto, H. and Yoo, I. D. 1997. Benzastatin E, F, and G: new indoline alkaloids with neronal cell protectin activity form Streptomyces nitrosporesus. Tetrahedron 53, 4309-4316.

20. Krieger, D. T. 1983. Brain peptides: what, where, and why? Science 222, 975-985.

21. Kwon, M. C., Kim, C. H., Kim, H. S., Hwang, B. Y. and Lee, H. Y. 2007. Anti-wrinkle activity of low molecular weight peptides derived from the collagen isolated from Asterias amurensis. Korean J Food Sci Technol 3, 625-629

22. Lehrer, R. I., Rosenman, M., Harwig, S. S. L., Jackson, R. and Eisenhaur, P. 1991. Ultrasensitive assay for endogenous antimicrobial polypeptides. J Immunol Methods 137, 167-173.

23. Li, C., Haug, T., Styrvold, O. B., Jørgensen, T. Ø. and Stensvåg, K. 2008. Strongylocins, novel antimicrobial peptides from the green sea urchin, Strongylocentrotus droebachiensis. Dev Comp Immunol 32, 1430-1440.

24. Martinage, A., Belaiche, D., Dupressoik, T. and Sautiere, P. 1983. Primary structure of histone H2A from gonads of the starfish Asterias rubens. Eur J Biochem 130, 465-472.
25. Matsunaga, S., Fusetani, N. and Konosu, S. 1985. Bioactive marine metabolites, IV. Isolation and the amino acid composition of discodermin A, an antimicrobial peptide, from the marine sponge Discodermia kiensis. J Nat Prod 48, 236-241.

26. Mitta, G., Hubert, F., Dyrynda, E. A., Boudry, P. and Roch, P. 2000. Mytilin B and MGD2, two antimicrobial peptides of marine mussels: gene structure and expression analysis. Dev Comp Immunol 24, 381-393.

27. Miyata, T., Tokunaga, F., Yoneya, T., Yoshikawa, K., Iwanaga, S., Niwa, M., Takao, T. and Shimonishi, Y. 1989. Antimicrobial peptides, isolated from horseshoe crab hemocytes, tachyplesin II, and polyphemusins I and II: chemical structures and biological activity. J Biochem 106, 663-668.

28. Ovchinnikova, T. V., Aleshina, G. M., Balandin, S. V., Krasnosdembskaya, A. D., Markelov, M. L., Frolova, E. I., Leonova, Y. F., Tagaev, A. A., Krasnodembsky, E. G. and Kokryakov, V. N. 2004. Purification and primary structure of two isoforms of arenicin, a novel antimicrobial peptide from marine polychaeta Arenicola marina. FEBS Lett 577, 209-214.

29. Ovchinnikova, T. V., Balandin, S. V., Aleshina, G. M., Tagaev, A. A., Leonova, Y. F., Krasnodembsky, E. D., Men'shenin, A. V. and Kokryakov, V. N. 2006. Aurelin, a novel antimicrobial peptide from jellyfish Aurelia aurita with structural features of defensins and channel-blocking toxins. Biochem Biophys Res Commun 348, 514-523.

30. Park, J. H., Kang, K. C., Baek, S. B., Lee, Y. H. and Rhee, K. S. 1991. Separation of antioxidant compounds from edible marine algae. Korean J Food Sci Technol 23, 256-261.

31. Rice-Evans, C. A. and Miller, N. J. 1996. Antioxidant activities of flavonoids as bioactive compounds of food. Biochem Soc Trans 24, 790-795.

32. Roch, G. J., Tello, J. A. and Sherwood, N. M. 2014. At the transition from invertebrates to vertebrates, a novel GnRH-like peptide emerges in amphioxus. Mol Bid Evol31, 765-778.

33. Seo, J. K., Crawford, J. M., Stone, K. L. and Noga, E. J. 2005. Purification of a novel arthropod defensin from the American oyster, Crassostrea virginica. Biochem Biophys Res Comm 338, 1998-2004.

34. Seo, J. K., Lee, M. J., Go, H. J., Kim, G. D., Jeong, H. D., Nam, B. H. and Park, N. G. 2013. Purification and antimicrobial function of ubiquitin isolated from the gill of Pacific oyster, Crassostrea gigas. Mol Immunol 53, 88-98.

35. Subramanian, S., Ross, N. W. and Mackinnon, S. L. 2009. Myxinidin, a novel antimicrobial peptide from the epidermal mucus of hagfish, Myxine glutinosa L. Mar Biotechnol (NY) 11, 748-757.

36. Waugh, D., Wang, Y., Hazon, N., Balment, R. J. and Conlon, J. M. 1993. Primary structures and biological activities of substance-P-related peptides from the brain of the dogfish, Scyliorhinus canicula. Eur J Biochem 214, 469-474. 


\section{초록 : 아무르불가사리 추출물의 생리활성}

고혜진 ${ }^{1} \cdot$ 조미정 ${ }^{2} \cdot$ 김태영 $^{1} \cdot$ 홍용기 $^{1} \cdot$ 김군도 ${ }^{2} \cdot$ 이병우 ${ }^{3} \cdot$ 박남규 $^{1 *}$

( ${ }^{1}$ 부경대학교 생물공학과, ${ }^{2}$ 부경대학교 미생물학과, ${ }^{3}$ 부경대학교 신소재시스템공학과)

아무르불가사리(Asterias amurensis)의 6가지의 조직 추출물들을 사용하여 항균활성, 항산화 활성 및 평활근에 대한 수축과 이완반응에 대한 활성을 측정하였다. $1 \%(\mathrm{v} / \mathrm{v})$ 초산용액을 사용하여 동결 건조한 샘플들을 추출하여 각각의 활성측정에 사용한 결과, 껍질을 제외한 모든 조직 추출물들은 E. coli D31에 대해 강한 항균활성을 나타내 었고, 근육 및 장관 추출물들은 별불가사리(Asterina pectinifera)의 DRM에 대해 수축반응을 나타냈다. 한편, 오징어 (Todarodes pacificus) 식도에 대한 수축반응은 실험에 사용한 모든 조직 추출물들에서 검출되었다. 특히, 간 추출물 의 수축활성은 다른 조직의 추출물의 활성에 비해 더 높았다. 뿐만 아니라 간, 근육 및 소화관 추출물은 졸복 (Takifugu pardalis)의 장관에 대해서 수축반응을 나타냈다. 별불가사리의 DRM에 대한 이완반응은 실험에 사용한 모든 조직 추출물들에서 활성을 나타냈다. 항산화 활성은 장관, 간 및 껍질의 추출물들에서 강하게 나타났다. 따라 서 아무르불가사리는 새로운 생체기능 조절물질의 발견에 대한 가능성을 지닌 자원이라는 것을 본 연구의 결과들 은 제시한다. 